\title{
LA IDENTIDAD NACIONAL COMO PRODUCCIÓN DISCURSIVA Y SU RELACIÓN CON EL CINE DE FICCIÓN
}

Por

\section{Manuel Silva Rodríguez}

Profesor asociado

Escuela de Comunicación Social

Facultad de Artes Integradas

Universidad del Valle

manuel.silva@correounivalle.edu.co

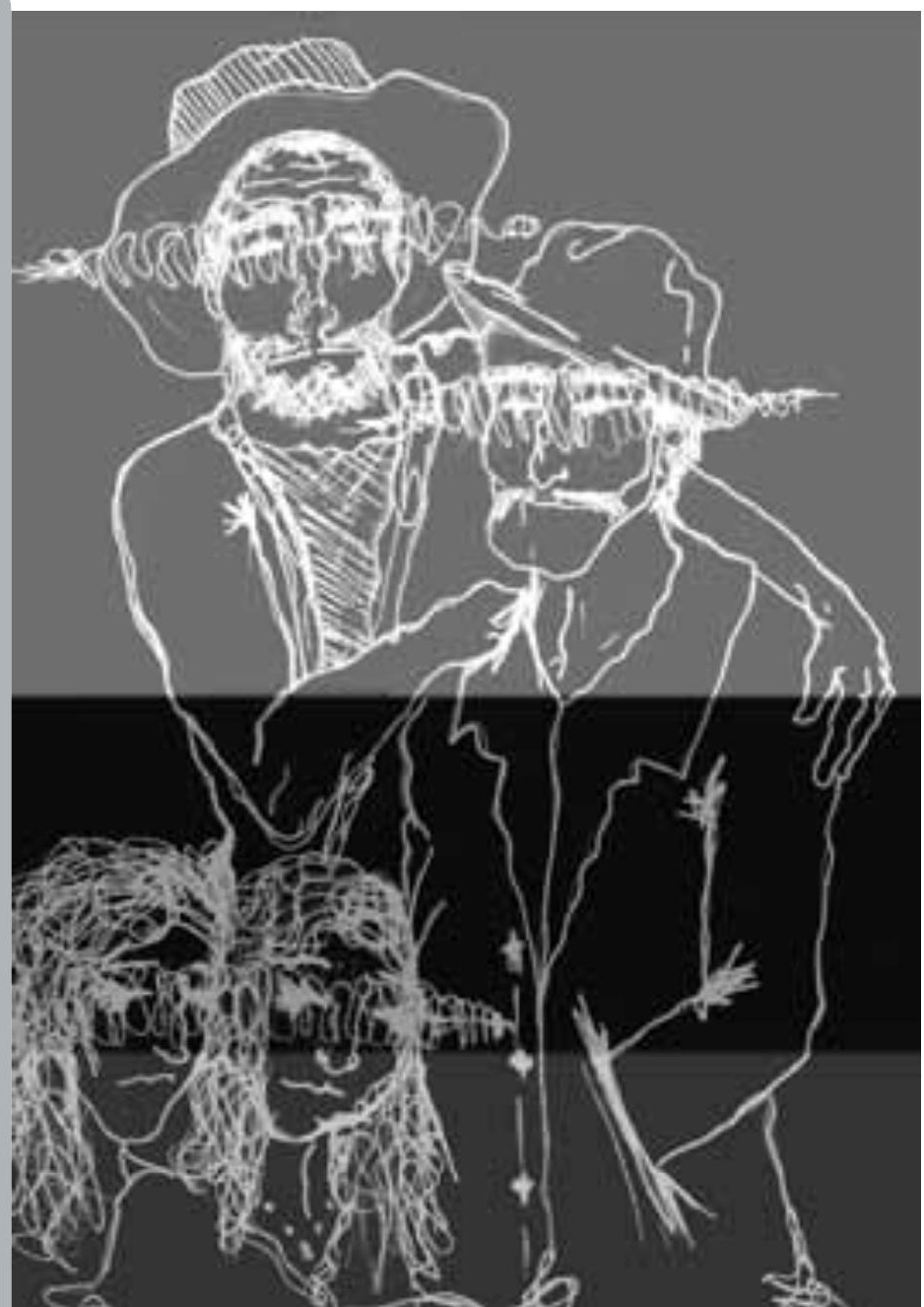

\section{Resumen:}

Con énfasis particular en el caso de Colombia, este artículo expone algunos elementos conceptuales e históricos sobre la formación de discursos identitarios nacionales y sobre la intervención del cine de ficción en tal proceso. Tras señalar cómo desde sus inicios el cine se aunó a una función desarrollada por la producción artística y simbólica desde la creación de los estados-nación, el texto formula algunas observaciones que plantean la pertinencia de pensar, en tiempos de globalización y multiculturalismo, la relación cine-identidad.

\section{Palabras Claves:}

Alteridad, cine colombiano, comunidad, ficción, historia,identidad, nación, tradición. 


\section{Introducción}

Este artículo toma como base parte del marco teórico y algunos aspectos de la investigación Imágenes del otro: Representaciones de la identidad colombiana ante otras culturas en producciones y coproducciones cinematográficas colombianas de ficción realizadas entre 1999 y 2009 ${ }^{1}$. Si bien la investigación tuvo como eje central la pregunta por los elementos que permiten apreciar, en un corpus de filmes recientes, representaciones de la identidad de los colombianos en su relación con personajes y culturas extranjeros, este escrito trasciende esa inquietud. En efecto, el texto indaga, de una manera más amplia, en el concepto de identidad, en su nexo con la formación de los estados-nación y en la mediación en su configuración práctica de productos culturales como el cine. En tal sentido, haciendo énfasis en el caso de Colombia y apuntando a la vigencia de la relación cine-identidad, el texto propone un acercamiento teórico e histórico a algunos de los componentes de tal relación.

\section{La cuestión de la identidad}

Nos recuerda Stuart Hall (1996) que la cuestión de la identidad recobró importancia en las últimas décadas del siglo XX, después de que permaneciera durante años fuera del centro del interés de las ciencias sociales. Hall se pregunta cuáles son las razones que devolvieron el tema a la actualidad y busca respuestas en dos direcciones: ¿después de la crítica a la cual fue sometido el concepto de identidad, éste qué sentido tiene hoy? Y, las preguntas que sirven de origen a su escrito, ¿quién necesita identidad hoy?, ¿por qué tiene vigencia el debate?

Al responder la primera pregunta Hall sintetiza una posición teórica que hoy es de uso corriente: el concepto de identidad ha sido despojado de sentidos y valores esencialistas. Esto es, ha perdido el dejo metafísico, de una propiedad sustantiva que en el pasado se atribuyó a los sujetos individuales y colectivos. En lugar de entenderla así, la identidad ha pasado a ser considerada como un predicado cambiante, expuesto a propósito de una forma de existencia y vinculado a unas condiciones históricas. Haciendo referencia al método utilizado por la deconstrucción, Hall señala que ésta, a diferencia de otras corrientes críticas, no sustituyó por otro el término «identidad», sino que lo sometió a «borradura». Ello no quiere decir que la cuestión de la identidad ahora designe un campo de problemas totalmente ajenos a los de antes. Lo que plantea, más bien, es mirarlos desde otra óptica: es "una idea que no puede usarse a la vieja usanza, 
pero sin la cual ciertas cuestiones clave no pueden pensarse en absoluto" (1996: 14). Parte de la nueva usanza, pues, es volver el contenido del término contra antiguas pretensiones esencialistas. Aunque el término se conserva, en la actualidad posee otro valor, no guarda el mismo sentido de antes.

Si bien la perspectiva que abrió la deconstrucción de tipo derrideana propició una inversión del contenido del concepto de «identidad», la perspectiva abierta por Foucault sobre el descentramiento del sujeto y la puesta en evidencia de su inscripción en prácticas discursivas señaló otro camino. En efecto, apunta Hall, desde este punto de vista la cuestión de la identidad vino a ser pensada como "el proceso de sujeción a las prácticas discursivas” (1996: 15), o sea, como la identificación con uno u otro discurso. Aunque, según Hall, al igual que el concepto de identidad el de identificación no está exento de dificultades, éste es preferible que aquél porque hace evidente que la identidad es la identificación con una o varias prácticas discursivas. Esto es, la representación de un sujeto histórico mediante su integración al tipo de orden que supone un determinado discurso.

Este modo de concebir el concepto descubre lo siguiente: por un lado, si las prácticas discursivas son históricas, contingentes y cambiantes, la identificación con ellas también puede serlo. En cuanto los discursos se transforman - y a un discurso se puede superponer otro o el contenido de uno puede variar con el tiempo, ya sea por la coyuntura social o política o por la moda-, las identificaciones con ellos también cambian. Este enfoque ha permitido pensar la identidad como una situación transitoria, como una cualidad que no está definida de una vez y para siempre. Por este motivo, haciendo referencia a la identidad individual, Zygmunt Bauman sostiene que "los individuos «no tienen una identidad», sino más bien deben enfrentarse con la larga, penosa e inacabada tarea de la identificación" (1999: 146). Lo mismo cabe decir para las colectividades: los grupos o comunidades no tienen una identidad suprahistórica.

Veamos lo anterior con más detalle. De un lado el planteamiento que sigo quiere hacer hincapié en que la identidad es una construcción discursiva. Aquello que se dice que un sujeto es en un momento es un predicado que resulta de la identificación de un ser con un determinado corpus discursivo. Lo que un sujeto cree que es o que otros creen que él es, en cuanto realidad social e histórica, no corresponde a una propiedad inmanente a él, a una cualidad metafísica o a un sello intrínseco dado por la naturaleza. Aquello con lo que se identifica un sujeto puede deberse a la imposición, a su elección o a su inmersión más o menos inconsciente en una serie de discursos y rutinas. O, para ser más exactos, de las tres cosas.

De ahí el carácter adquirido y, por lo tanto, cambiante, proteico y contingente que desde las teorías sociales y las humanidades se atribuye actualmente a la identidad. Aquello con lo cual nos identificamos en un momento dado no será necesariamente lo mismo con lo que nos identificaremos después, aunque sigamos «siendo los mismos». De ahí, también, que se asevere que la identidad es una conquista y una elección permanentes. De acuerdo con Hall:

\footnotetext{
En el lenguaje del sentido común, la identificación se construye sobre la base del reconocimiento de algún origen común o unas características compartidas con otra persona o grupo o con un ideal, y con el vallado natural de la solidaridad y la lealtad establecidas sobre este fundamento. En contraste con el «naturalismo» de esta definición, el enfoque discursivo ve la identificación como una construcción, un proceso nunca terminado: siempre «en proceso». No está determinado, en el sentido de que siempre es posible «ganarlo» o «perderlo», sostenerlo o abandonarlo. Aunque no carece de condiciones determinadas de existencia, que incluyen los recursos materiales y simbólicos necesarios para sostenerla, la identificación es en definitiva condicional y se afinca en la contingencia (1996: 15).
} 
Ahora bien, establecer que la «identificación con» y en general la construcción de la identidad acontecen en el ámbito discursivo es reconocer que estos procesos ocurren en el territorio del lenguaje. «Identificarse con» o «identificar a otro con» es vincular una forma de existencia con predicados, imágenes y símbolos. "Las identidades, en consecuencia, se construyen dentro de la representación y no fuera de ella” (Hall, 1996: 17). «Identificarse con», entonces, es construir una representación de un sujeto, ya sea de sí mismo o de otro.

Por tal razón, reitero, el concepto de identidad aceptado en la actualidad está desligado hace tiempo de un carácter cerrado, estático y metafísico. La identidad se entiende hoy como una construcción cultural, social e histórica realizada en el ámbito del lenguaje, de los múltiples discursos que circulan en el marco de las relaciones sociales. Vista así, la identidad es una representación construida acerca de una forma de existencia individual o colectiva, es un discurso que se cree y se acepta. La expresión más extrema de este concepto es que la identidad, en cuanto a su nivel ontológico, tiene lugar en la imaginación: es resultado de conjuntar diversidad de elementos significativos y de dotarlos de un sentido integral; o sea, es también un relato. Aunque quizás en los individuos y los grupos no exista conciencia de ello, la construcción de la identidad opera con la lógica ficcionalizante e imaginativa de la operación de configurar un relato: ficcionaliza en cuanto, según pone en evidencia Paul Ricoeur, muestra como acordes elementos que, en el acontecer histórico, se experimentan separados, discordes ${ }^{2}$. Aceptar este hecho, por otra parte, no significa restar valor o potencial a la identidad en el dominio práctico:

la naturaleza necesariamente ficcional de este proceso no socaba en modo alguno su efectividad discursiva, material o política, aun cuando la pertenencia, la «sutura en el relato» a través de la cual surgen las identidades resida, en parte, en lo imaginario (así como en lo simbólico) y, por lo tanto, siempre se construya en parte en la fantasía o, al menos, dentro de un campo fantasmático (Hall, 1996: 18).

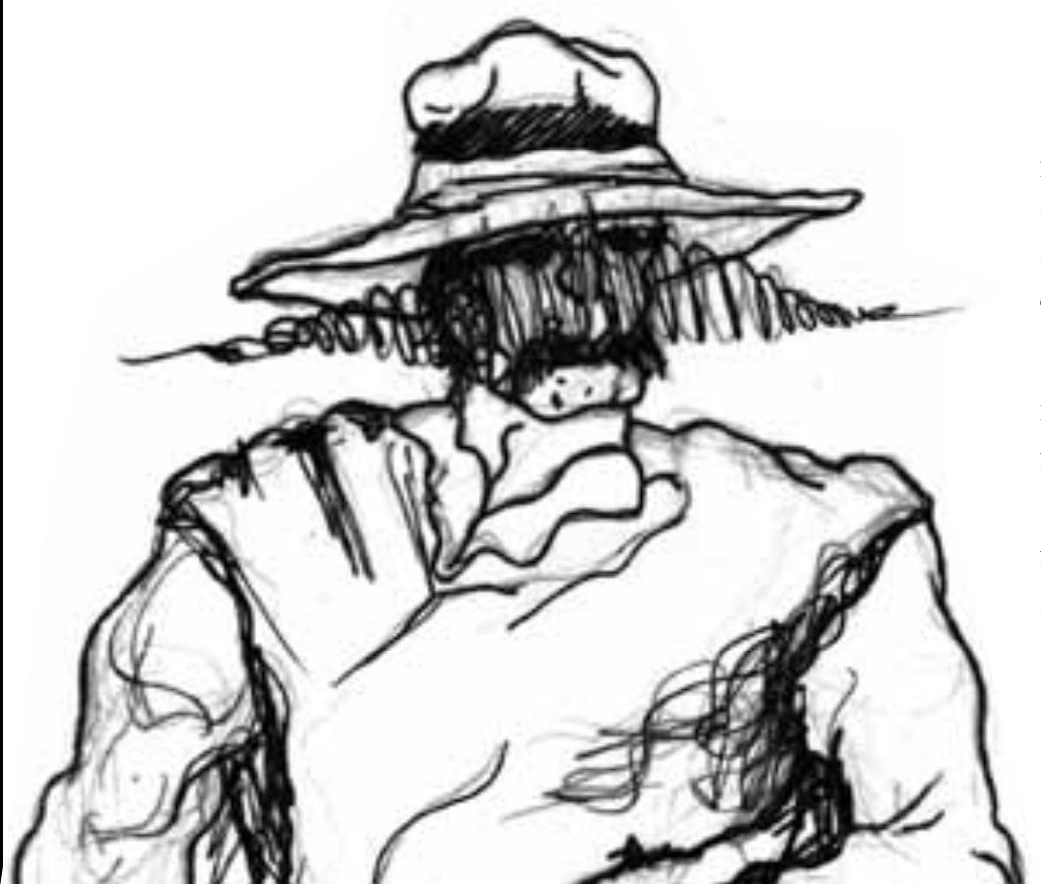

Es pertinente advertir, no obstante, que si bien esta manera de entender la identidad es hoy de uso corriente a ella no le faltan críticas. Un ejemplo es un artículo polémico de Jorge Orlando Melo, quien rechaza que se siga usando el término «identidad» por las dificultades que implica dotarlo de contenido y, más aún, por el uso que hacen de él agentes relacionados con algún tipo de poder para legitimar visiones unilaterales de lo que identificaría a un grupo social. Para Melo, esta noción de identidad es una suerte de callejón sin salida atrapada en sus premisas. Melo describe esta concepción como "«invencionista», «constructivista» $\mathrm{O}$ «construccionista»" (2006: S.P.), en la cual "lo único que constituye la identidad es el discurso por el cual sus miembros se reconocen como miembros de esa comunidad. Pero el contenido de ese discurso, hay que recordarlo, es relativamente arbitrario e indeterminable” (2006: S.P.). Por lo tanto, agrega, "está claro que esta "identidad" es 
una propuesta arbitraria, una propuesta política, una ideología, algo que podemos aceptar o rechazar." (2006: S.P.) En conclusión, anota, “la “identidad discursiva” o construida no logra evitar ser una propuesta más o menos abusiva y arbitraria a la que se induce a la población, o un error compartido masivamente" (2006: S.P.).

Contra tal posición, cabe recordar precisamente lo que quedó dicho con Stuart Hall: la identidad, entendida como discurso, no es ajena a la intencionalidad del sujeto de la enunciación. Ella corresponde a la toma de una posición estratégica: tras el discurso que nombra hay alguien que enuncia, hay una intencionalidad.Y para esta perspectiva del estudio de las identidades resulta de interés reconocer esas posiciones.

De otro lado, sostener que la identidad se construye implica pensar que este proceso conjuga diversos elementos. Además de la representación de sí, la alteridad figura como un elemento constitutivo de la identidad. El acto de «identificarse con» tiene implícito un sentido negativo: «identificarse con» es el reverso de «diferenciarse de», de «no identificarse con». Esta diferenciación otorgará relieve a ese o eso que no se es, a lo que no se parece a la idea que de sí se forma un sujeto, a lo diferente, al «otro», a la alteridad. Afirmar, para utilizar unos términos del siglo XIX, que soy criollo es aseverar implícitamente que no soy chapetón. Es vincular a mi existencia un discurso que me diferencia del discurso de los chapetones.

Este hecho muestra, por una parte, que adoptar una identidad corresponde a una toma de posición en la sociedad; y, por otra, que esta decisión implica a la vez una tarea - perseverar en la decisión, si se quiere conservar el sentido de la elección - y un proceso de exclusión. «Identificarse con» es establecer un adentro y un afuera: "Las identidades se construyen a través de la diferencia, no al margen de ella. (...) A lo largo de sus trayectorias, las identidades pueden funcionar como puntos de identificación y adhesión sólo debido a su capacidad de excluir, de omitir, de dejar «afuera»" (Hall, 1996: 18). Volviendo a nuestro ejemplo, el hecho es significativo porque si bien los chapetones y los criollos estaban situados en una misma constelación histórica, cada uno ocupaba en los campos social, cultural y político una posición en relación con el otro.

Pero el «otro» no sólo cuenta porque es aquella instancia respecto de la cual un sujeto ocupa una posición. El otro también cuenta porque, como expone la tesis lacaniana del estadio del espejo, nos devuelve una imagen de nosotros. El resultado de este movimiento es que la representación que construimos de nosotros implica la imagen que los «otros» han forjado de nosotros. Como asegura Fernando Aínsa, "la «representación» que una sociedad se hace de sí misma no basta para configurar su identidad. Es necesario — y muchas veces en forma abiertamente contradictoria - integrar esta representación con la idea que los «demás», es decir, los integrantes de «otros grupos culturales», se hacen de «esa» identidad" (1986: 30). Entonces, ¿cómo nos ve el otro?, ¿qué dice de nosotros?, ¿con qué nos identifica?, ¿qué somos para él?, ¿desde dónde nos mira? De acuerdo con el otro en el cual nos miremos tendremos una u otra imagen nuestra. Por eso, como destaca Aínsa, la relación con el otro puede ser contradictoria. Incluso, antes que caracterizarse por la armonía en ella parece predominar la confrontación. La imagen que el otro refleja de nosotros pocas veces nos complace, no siempre corresponde con el concepto que tenemos de sí. Pero esta relación no sólo es dialéctica en este sentido. Ya veíamos que además de denotar diferencia la identidad también connota exclusión ${ }^{3}$. 
Amén de la alteridad, en la representación que construimos de nosotros también cuentan la memoria y la historia. Como lo enseña Ricoeur siguiendo a Heidegger, la temporalidad es una de las dimensiones propias de la compresión de lo que somos a través del sentido que asignamos a nuestras acciones cuando las unimos en secuencias del tipo causa-efecto. Damos sentido a nuestra vida en el tiempo.Y una facultad humana para volver sobre algo del ser consumado en el tiempo es la memoria ${ }^{4}$, que en los ámbitos social y cultural encuentra una de sus formas de objetivación en la historia: en la representación de aquello que ha pasado, de actos y acontecimientos que por algún motivo merecen ser recordados por una persona o un grupo. En la configuración de la identidad, la historia nos da un marco, nos sitúa en relación con un camino que se va transitando. La historia, que como modalidad discursiva no revive el pasado sino que crea representaciones de él, es decir, que nos permite imaginarlo y comprenderlo a través de la recreación en el lenguaje de lo acontecido ${ }^{5}$.

En esta concepción de la historia nos encontramos de nuevo con el papel fundamental del lenguaje para dar existencia discursiva a la realidad pasada; a la realidad consumada en el tiempo y sólo aprehensible en el discurso que, desde cada presente, representa lo ausente. Aquí se advierte el sentido de la afirmación de Hall, según la cual las identidades "se relacionan tanto con la invención de la tradición como con la tradición misma, y nos obligan a leerla no como una reiteración incesante sino como «lo mismo que cambia»: no el presunto retorno a las raíces sino una aceptación de nuestros «derroteros»" (1996:18). En la relación entre la construcción de la identidad y el pasado no se trata, pues, de ser fiel a una historia estática, a la imagen de un pasado original y originario, sino de situarnos en una trayectoria que, siendo la misma, se ve diferente desde cada nuevo punto del camino. Es decir, mirar el pasado desde el presente, ponerlo en relación con la actualidad.

En este lugar es necesario ampliar la noción de historia más allá de sus consideraciones como ciencia y como escritura sobre el pasado. La historia no sólo está en los llamados libros de historia. De hecho, sólo una minoría conoce la historia por lo que se dice en los textos historiográficos. En el mundo práctico las personas entran en relación con la historia a través de otros medios, es decir con diversidad de producciones culturales. Fernando Aínsa anota que "obras, costumbres y creaciones de todo tipo forman un «patrimonio»", ellas "permiten reconocer y conocer una cultura a través de su historia" (1986: 29). La historia y la memoria, sujetas a las perspectivas de cada presente, permiten una ubicación temporal y espacial, una identificación con una parte de lo pasado en una tradición localizada en un territorio determinado.

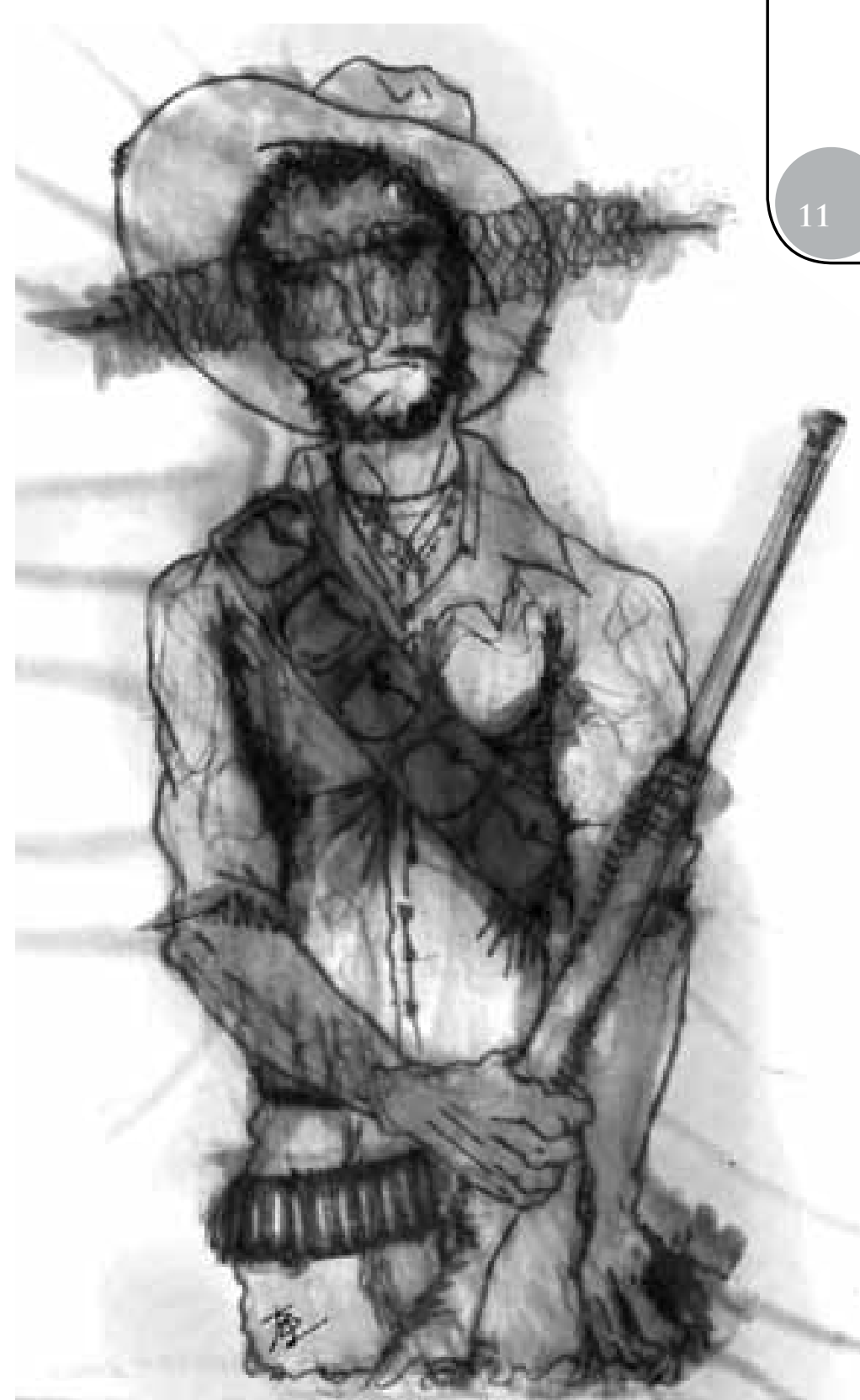


Aceptar, entonces, que "las identidades se construyen dentro del discurso y no fuera de él” (Hall, 1996: 18), que residen en la imaginación, que son un tipo de ficción en el cual creemos, obligan a preguntarse por el sentido social de estos discursos y por la producción cultural que les da cuerpo. En efecto, aunque la identidad sea discurso, necesita mostrarse. Como señala Aínsa, "los pueblos, como los individuos, necesitan una «cristalización» del concepto para poder representarse a sí mismos y ante los demás” (1986: 29).

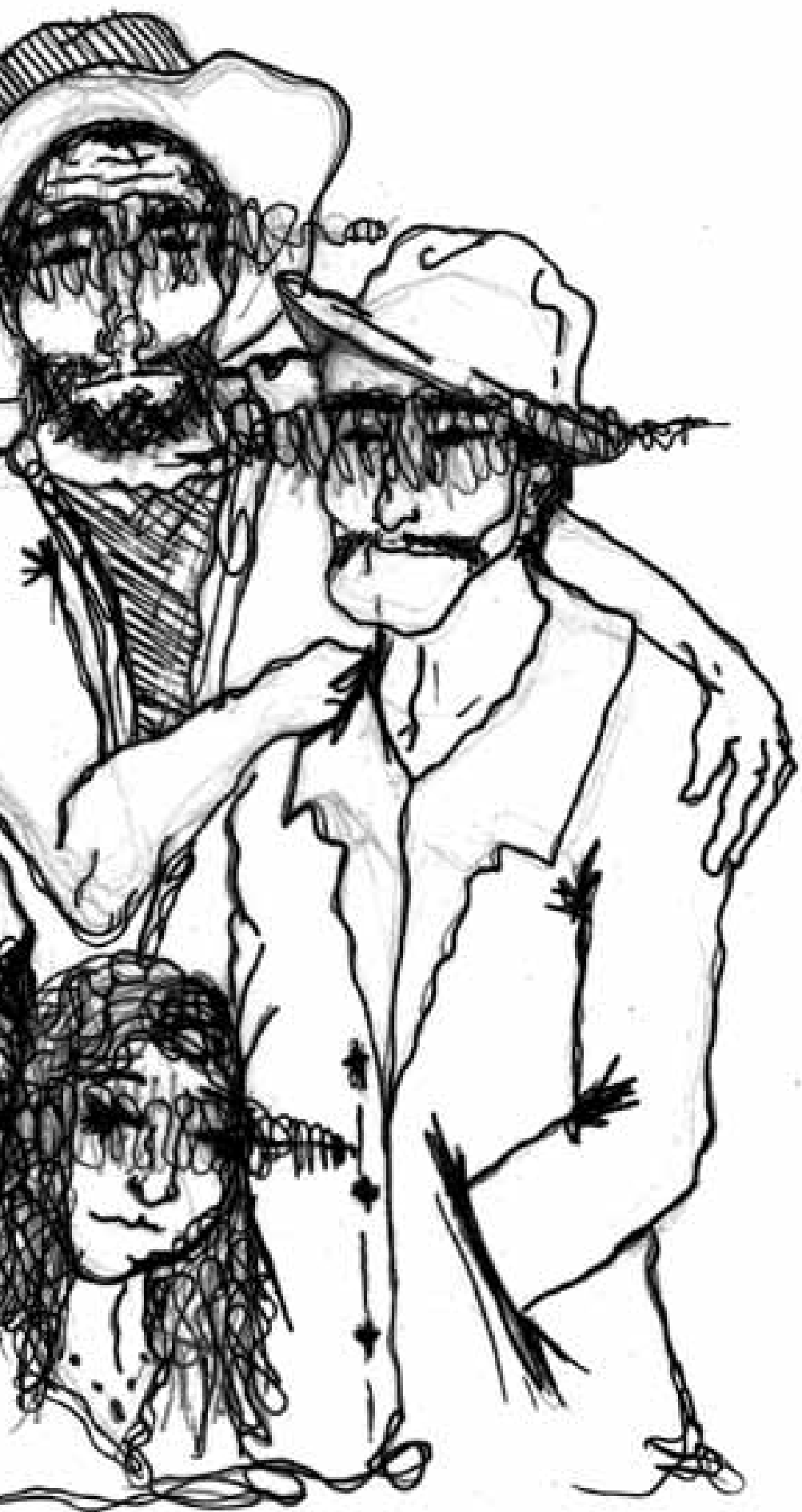

\section{Identidades nacionales}

En este punto el primer término a poner en consideración es el de comunidad. Como apunta Zygmunt Bauman, comunidad es una de esas palabras que además de comunicar un significado produce una sensación: "sea cual sea el significado de «comunidad», está bien «tener una comunidad», «estar en comunidad»" (2001b:7). El sociólogo polaco llama la atención acerca de que la comunidad, en cualquier caso, evoca algo positivo, bueno, cálido. En efecto, la comunidad despierta un sentimiento de pertenencia, de protección, de la existencia de una comunión entre los miembros del grupo gracias al mantenimiento de un vínculo. Al mismo tiempo, este sentimiento genera un espacio imaginario que connota un adentro y un afuera. La comunidad, dice Bauman, "es un lugar «cálido», un lugar acogedor y confortable". Por el contrario, "afuera, en la calle, acechan todo tipo de peligros: tenemos que estar alerta cuando salimos, vigilar con quién hablamos y quién nos habla", mientras "dentro, en comunidad, podemos relajarnos; nos sentimos seguros, no hay peligros emboscados en rincones oscuros" (2001b: 8). En oposición al afuera, el interior de la comunidad es un ámbito familiar, común, cercano. El exterior, en cambio, corresponde a lo extraño, lo ajeno, lo desconocido. Como afirma Bauman, en "una comunidad todos nos entendemos bien, podemos confiar en lo que oímos, estamos seguros la mayor parte del tiempo y rarísima vez sufrimos perplejidades o sobresaltos. Nunca somos extraños los unos para los otros" (2001b: 8). Pues bien, ¿de dónde proviene esta idea de la comunidad? ¿Si existe tal comunidad, cómo es su existencia? 
Esta manera de entender la comunidad emana de un anhelo. De acuerdo con Richard Sennett, en la sociología del siglo XIX Ferdinand Tönnies acuñó la distinción entre comunidad (gemeinschaft) y sociedad (gesellschaft). Y decimos distinción porque ambos términos nombran realidades diferentes. El primero "se refiere a la comunidad en el sentido de las relaciones emocionales plenas y abiertas con los demás". Según Sennett, para Tönnies "la gemeinschaft existía en el mundo precapitalista y preurbanizado de fines de la Edad Media o en las sociedades tradicionales" (1978: $275,276)$. Esta idea de comunidad hunde su raíz en la emotividad y sus posibilidades de existencia — si es que existió alguna vez- se sitúan en un pasado premoderno. Corresponde a la imagen formada sobre el clan o la tribu como grupos cuyos distintos integrantes se conocían y compartiendo unos vínculos sanguíneos o afectivos y un territorio establecían entre ellos un sentimiento de unidad. Tal modelo de sociabilidad, como subraya Sennett, es distinto del que designa el segundo término: el tipo de relaciones propio de la sociedad moderna más que contar con jerarquías fijas, con vínculos directos y con grupos estáticos, se caracteriza por la división del trabajo, por la atomización y, agregamos, por la movilidad de las gentes ${ }^{6}$.

La existencia de tal modelo de comunidad se pone en cuestión porque, como lo destaca Jean-Luc Nancy, esa idea obedece a un deseo: antes que a una experiencia histórica propiamente dicha, se debe a la proyección de un deseo oculto en la mirada que han posado sectores hegemónicos sobre grupos sociales desconocidos, diferentes o, incluso, imaginados. Nancy advierte que “(e)s necesario sospechar de esta conciencia (de la pérdida de la comunidad), ante todo porque parece acompañar a Occidente desde sus comienzos: a cada momento de su historia, se ha entregado ya a la nostalgia de una comunidad más arcaica, y desaparecida, al lamento por una familiaridad, por una fraternidad y una convivialidad perdidas” (1986: 27). Según Nancy, Rousseau es el primer pensador moderno que interpretó el origen de la sociedad moderna como una ruptura con el modelo de la comunidad. Desde entonces, afirma Nancy, "(h) asta nosotros la historia tendrá que ser pensada sobre un fondo de comunidad perdida - y por reencontrar o reconstituir" (1986: 26). Esta concepción de la comunidad, pues, debe más al mito que a la historia. Según Sennett, el mismo Tönnies se lamentaba por la pérdida de la comunidad mientras reconocía que sólo un romántico podría creer en su reconquista.

Pues bien, eso es lo que parece reposar en el fondo de ese calor confortable que Bauman atribuye a la comunidad: un mito. En la idea de comunidad late el mito del paraíso perdido, de la Arcadia añorada, de la utopía. Como sostiene Bauman haciendo referencia a Raymond Williams, "lo notable de la comunidad es que es algo que «siempre ha sido». Podríamos añadir: o que siempre existirá en el futuro. Comunidad es hoy otro nombre para referirse al paraíso perdido al que deseamos con todas nuestras fuerzas volver, por lo que buscamos febrilmente los caminos que puedan llevarnos alli'” (2001b: 9).

Esta concepción de la comunidad, precisa Nancy, está hecha "de la difusión o de la impregnación de una identidad en una pluralidad con la que cada miembro (...) no se identifica más que por la mediación suplementaria de su identificación con el cuerpo vivo de la comunidad" (1986: 26-27). Dicho de otra manera, la concepción de esta pretendida unidad y el anhelo de su consecución y mantenimiento son posibles por la identificación de una pluralidad de miembros con ideas y valores encarnados en la comunidad. Y es en el tránsito de la sociedad feudal a la sociedad burguesa que — con la creación de los estados-nación europeos, primero, y con el paso de las colonias del Nuevo Mundo a las nuevas repúblicas, después - ese deseo de unidad va a servir de base emocional para instituir una realidad sicológica, social, económica y política: la nación ${ }^{7}$. Cada nación será entonces un proyecto, una comunidad a construir, una identidad a establecer y conservar. 
Es en ese tránsito donde por primera vez la pregunta por la identidad va a cobrar una actividad inédita. Según Sennett, en esa transición se estableció una correlación entre los ideales que encarna la comunidad y la identidad colectiva: "Cualquier tipo de comunidad es algo más que un grupo de costumbres, comportamientos o actitudes acerca de otras gentes. Una comunidad también es una identidad colectiva; es una manera de decir quiénes somos «nosotros»” (1978: 276). Así las cosas, no parece apresurado afirmar que la identidad colectiva tiene fundamento en un proyecto doble: el de conservar y prolongar el sentimiento de unos lazos de unión, los cuales, a su vez, se sustentan en un presunto pasado de comunión, de esfuerzo compartido y de armonía.

Ahora bien, si seguimos a Sennett, ¿cómo se puede decir quiénes somos «nosotros» si con el advenimiento de la vida urbana este «nosotros» empezó a referir una cantidad de individuos para la cual resulta imposible mantener una comunicación cara a cara? Para Sennett, la cuestión encuentra sentido en cuanto los miembros de la sociedad "pudiesen alcanzar un retrato de sí mismos como una totalidad" (1978: 276). La cuestión, por lo tanto, es cómo llegan a conformarse "esos retratos de la personalidad colectiva" (1978: 276). Y cómo se conforman cuando, para dotar de actualidad a la pregunta, ese «nosotros» pasó de referir una supuesta unidad en un marco territorial y formal presuntamente homogéneo y estable, el del estado-nación, a situar esa pretensión en un marco caracterizado por la heterogeneidad y la movilidad.

De acuerdo con B. Anderson (1983), la creación de los estados-nación a finales del siglo XVIII en Europa supuso un esfuerzo por agrupar en un orden artificial, diseñado por las nuevas instancias de poder, los antiguos grupos sociales y las culturas locales que, bajo los modelos feudal y monárquico, se encontraban dispersos en el territorio y gozaban de cierta autonomía. Como lo recuerdan Martín-Barbero (1998) ${ }^{8}$ y Bauman (1999) ${ }^{9}$, además de la violencia física esta empresa acarreó —y sigue acarreando en cada presente por la imposición de unos valores y la resistencia que éstos puedan encontrar - un gran despliegue de recursos para instituir un orden simbólico y formal sobre aquella diversidad preexistente. La adopción de una sola lengua, una sola religión, un solo sistema medicinal o un gobierno son ejemplos de ello.

Pero hay otro hecho que interesa subrayar: donde antes había diversidad, si se quiere distintas comunidades, con la instauración de ese orden formal llamado estado-nación se imponía la necesidad de crear un sentido único de pertenencia y unidad, o sea, un sentido de comunidad, una identidad colectiva. Esto es, como sostiene Bauman citando a JackYoung, “«La identidad se inventa justo cuando se colapsa la comunidad»” (2001b: 22). Para generar ese vínculo había que compartir un pasado y un proyecto, se tornaba necesario realizar un ajuste del pasado al presente. Una solución a esta necesidad se halló en lo que Hobsbawm ha llamado la invención de tradiciones: en que los estamentos del poder de la nueva formación establezcan como rasgos propios de la vida colectiva unos valores y unos ritos, los cuales muestran la nueva realidad en continuidad con la precedente ${ }^{10}$. Aquí resulta relevante el proceso de acuñación de una historia común y de nuevos valores, ya sea por su introducción o por la resignificación, en un nuevo contexto, del pasado de la agrupación anterior. 
La invención de la tradición contribuye a lo que, por su lado, Benedict Anderson entiende también como la construcción de una realidad imaginaria: la nación. En efecto, Anderson define la nación como un artefacto cultural (1983: 21). Según este autor, la nación es una "comunidad política imaginada como inherentemente limitada y soberana" producto de un cruce de fuerzas históricas: "Es imaginada porque aun los miembros de la nación más pequeña no conocerán jamás a la mayoría de sus compatriotas, no los verán ni oirán jamás hablar de ellos, pero en la mente de cada uno vive la imagen de su comunión" (1983: 23).

La posición de Anderson tiene valor por distintas razones. Una: define a la nación como una comunidad. Dos: como una comunidad política imaginada. Ya hemos entendido que el sentido atribuido a la comunidad no corresponde a una existencia objetiva, sino a un sentimiento compartido que se ha forjado alrededor de ideales y valores fijados en discursos y prácticas. Desde este punto de vista, en tanto que comunidad la nación es un anhelo. De hecho, llegados a este lugar decir que la nación es una "comunidad imaginada" parece redundante. Se hace comprensible, entonces, la afirmación de Anderson según la cual la nación "se imagina como comunidad porque, independientemente de la desigualdad y la explotación que en efecto puedan prevalecer en cada caso, la nación se concibe siempre como un compañerismo profundo, horizontal" (1983: 25).

Queda por observar aún el cariz político de esta comunidad. Si bien Anderson no específica su noción de política, el sentido extensivo al término parece implicado en el carácter soberano que este autor atribuye a la nación: "Se imagina soberana porque el concepto nació en una época en que la Ilustración y la Revolución estaban destruyendo la legitimidad del reino dinástico jerárquico, divinamente ordenado" (1983: 25). En este sentido, se considera política en cuanto se forma por la movilización de una voluntad y una autonomía colectivas, orientadas hacia la creación de un orden compartido cuyo poder se centraliza en el Estado y sus funcionarios, pero cuyo sentido y expresión no se limita a éste ${ }^{11}$ : es decir, en su dimensión política la identidad nacional es un campo de disputa por cuanto los distintos discursos que circulan o luchan por circular en la esfera pública antes que consensos pueden denotar disensos, resistencias y exclusiones. De ahí, como se dijo más atrás, que la identidad es inacabada, que se conciba como una conquista permanente: en términos dialécticos, la identidad total de los ciudadanos de una nación puede estar siempre presente en el deseo aunque en términos efectivos parezca un imposible alcanzarla, salvo si el discurso con mayor poder se impone borrando las diferencias a través de distintas formas de violencia. 
En la perspectiva de Anderson, pues, la nación puede ser entendida como la construcción de una idea compartida, alrededor de la cual se crean unos lazos, un sentimiento de unidad y pertenencia y unas expectativas. Es una comunidad imaginada porque, como lo resalta el autor, todos los que participan de esa idea y del sentimiento que emana de ella no se conocen, no mantienen una comunicación directa, pero sí sostienen un vínculo imaginario. $\mathrm{Si}$ bien el conocimiento de todos los miembros de la comunidad nacional no es posible, su unidad sí puede llegar a considerarse por el sentimiento de unión y de diferenciación en relación con otros surgido del hecho de haber nacido en los límites fijados en un territorio y por compartir unos valores asociados con la vida en él. Los individuos que integran ese conjunto se sienten parte de él porque aceptan unos nexos comunes: "en la mente de cada uno (de los miembros) vive la imagen de su comunión" (1983: 23).

Decir, por otra parte, que esa unidad es imaginaria no significa que ella carezca de fuerza o que no mantenga relación con el orden histórico. En cuanto un grupo se reconoce como comunidad, ya hemos visto que alrededor de la fuerza que cobra ese sentimiento se establecen unas fronteras afectivas e ideológicas, un adentro y un afuera que diferencian a quienes pertenecen a ese espacio de aquellos que no. En el marco del territorio, la expresión formal de estas fronteras se representa en el mapa, en los pasos fronterizos. De ahí que Anderson también defina la nación como una comunidad que se imagina limitada. O sea, la nación establece unos límites entre propios y extraños, entre nacionales y extranjeros según los términos jurídicos. Ese sentimiento de unidad y pertenencia y la fuerza que dimana de él se genera y se sostiene, entre otras estrategias, a través de la producción, la circulación y el uso de discursos; de crear imágenes de la nación, de señalar, ya sea de manera consciente o no, cuáles valores - traducidos en juicios, creencias, costumbres, actos, leyes, etc. - corresponden y cuáles no con aquello que en un momento determinado debe servir de punto de convergencia a los miembros de esa comunidad.

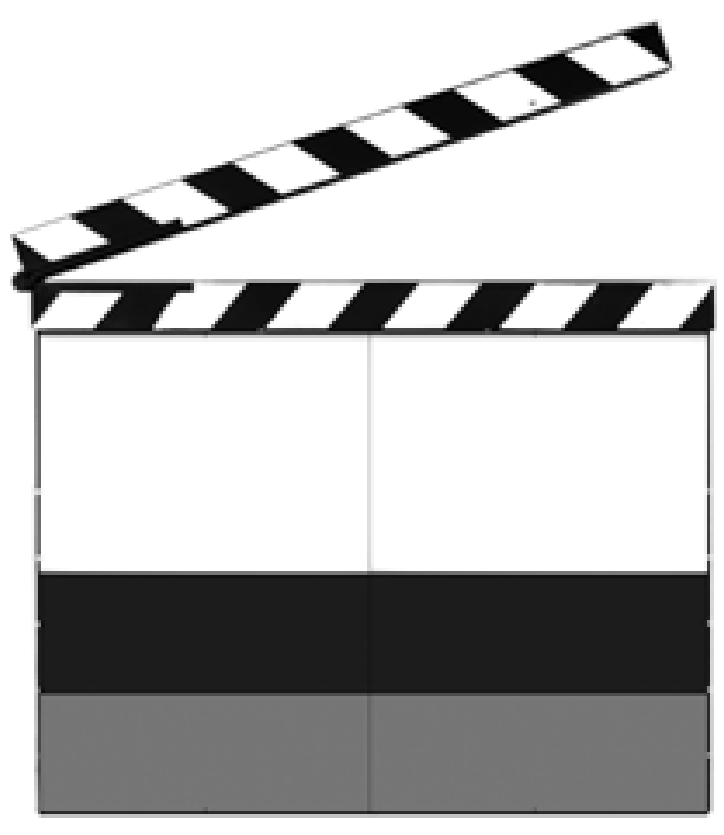

Ese sentimiento del que venimos hablando cuando se sublima en ideología se convierte en nacionalismo. Al decir de Anderson, el nacionalismo es tan inventado como la nación: éste es fundamento de aquélla. Anderson subraya que la nación y el nacionalismo que le sirve de base tienen una "legitimidad emocional profunda" (1983:21). De esta manera llama la atención el carácter emocional de ambas categorías. Antes que contenidos racionales, la nación y el nacionalismo fundan un orden con arraigo en creencias y afectos. En la creencia en un orden trascendente - como lo fue Dios en la Edad Media, o después del XVIII el estadonación que promete emancipación y bienestar - que agrupa a los individuos y funda la comunidad; y en el sentimiento de unidad y cohesión que genera la pertenencia a esa comunidad $^{12}$.

Cuando Anderson afirma que todos los miembros de una nación no se conocen pero en sus mentes hay elementos compartidos que despiertan un sentimiento de unión, nos hallamos frente a un proceso de comunicación. Vemos, pues, que aquello que Sennett llama un "retrato" de la totalidad, Anderson lo denomina una "imagen común". Para ambos es similar la función de esa imagen: constituir el referente de la comunidad y, negativamente, diferenciarla de otras formaciones colectivas. Sennett pregunta lo siguiente: "Si las gentes no se hablan en las calles, ¿cómo habrán de saber quiénes son como grupo?” (1978: 277). Al igual que Anderson, Sennett encuentra respuesta en la imaginación. Para él, el tipo de sociedad que se desarrolla a partir del siglo XVIII genera entre sus miembros unos vínculos 
comunes sustentados en la fantasía, "una comunidad que tiene una personalidad colectiva generada por la fantasía común” (1978: 277). Pero si bien se reconoce esta capacidad a la imaginación, cabe preguntar: ¿cómo se crean estas imágenes?, ¿dónde se encuentran? Es aquí donde los medios de comunicación —amén de los distintos productos y prácticas culturales - desde sus primeros momentos en el siglo XVIII empiezan a jugar un papel importante, pues ellos son instancias que construyen, reproducen y hacen circular discursos que proporcionan imágenes de la comunidad nacional a sus miembros ${ }^{13}$.

\section{La invención de Colombia y la producción cultural como su soporte}

Como se sabe, sólo hasta mediados del siglo XIX el Nuevo Mundo empezó a llamarse América. La nueva comunidad continental, fundada en un territorio donde antes había diversidad de grupos étnicos con disímiles niveles de desarrollo e incluso incomunicados entre sí, se configuró en un acelerado proceso histórico cuyos orígenes y proyectos se fijaron a partir del desembarco abrupto de los europeos. En efecto, el corte histórico y cultural que significó la llegada de los europeos a este lado del Atlántico supuso para las sociedades que empezaron a configurarse aquí el establecer unos atributos que permitieran, por un lado, diferenciarse del mundo europeo y, por otro, generar un sentido de cohesión y unidad. Algunos de esos atributos ya habían adquirido presencia en el imaginario con los relatos introducidos por los europeos sobre su reencuentro en estas tierras con el paraíso perdido, y otros fueron cobrando fuerza con la urgencia de encontrar «lo propio» de los pueblos agrupados en el Nuevo Mundo ${ }^{14}$. Como afirman Guerrero y Lozada citando al historiador O’Gorman, "América fue inventada, no descubierta. Esta invención marcó buena parte del destino de esta región continental. «Indoamérica», «América Latina» o «Latinoamérica» fueron nombres que se otorgaron a una construcción imaginaria y al reconocimiento que hicieron algunos países de esta región del mundo sobre algunas similitudes entre ellos" (2007: 25).

La invención de América como artefacto imaginario, para utilizar la expresión de Benedict Anderson, se cimentó entonces en la creación de unas imágenes con las cuales los habitantes de esta zona del mundo se identificaran, por las cuales se sintieran americanos. De esta manera, la "noción de «identidad» fue el pilar sobre el cual se edificó 
esta construcción imaginaria. A raíz de la emancipación política que tuvieron los pueblos de América del coloniaje ibérico en la primera mitad del siglo XIX, surgió la necesidad de construir nuevas naciones, y con ello la construcción de una nueva identidad o de nuevas y diversas identidades" (Guerrero y Lozada, 2007: 26). Ahí, justamente, se inserta el discurso de Bolívar sintetizado en su programática Carta de Jamaica, en la cual imagina una gran nación americana antes de regresar del exilio y acometer su empresa libertadora.

Tales circunstancias hacen parte del marco histórico donde surgió la nación que hoy recibe el nombre de Colombia. Contrario a la voluntad de Bolívar, los líderes militares que también eran los líderes políticos — de los territorios que integraron la Gran Colombia no creyeron en esa posible comunión de naciones. Tras el intento de reunir en 1819 en un solo cuerpo jurídico a la Nueva Granada, Venezuela y Quito, entre 1829 y 1830 esa unidad formal se disolvió. Sin embargo, como lo describe Hans-Joachin König (1988), en la Nueva Granada ya se habían sembrado las semillas para configurar un discurso nacionalista. El recorrido que, aproximadamente desde mediados del siglo XVIII, habían trazado los criollos para impulsar la campaña de independencia era un legado ideológico que sobrevivía en la Nueva Granada tras la fugaz y fallida unidad de la Gran Colombia. Según König (1988: 195 ss., 512 ss.), la incorporación a los discursos proindependentistas del concepto de patria, así como la elevación a la categoría de símbolos compartidos de la metáfora de la familia, el indio como imagen de la opresión, la promesa de la libertad y, en particular, el concepto de ciudadano como categoría que fundía lo formal-jurídico con el sentimiento de pertenencia a un territorio, fueron instrumentos útiles para alcanzar el propósito de conformar un sentido de nación y un sentimiento anticolonialista ${ }^{15}$.

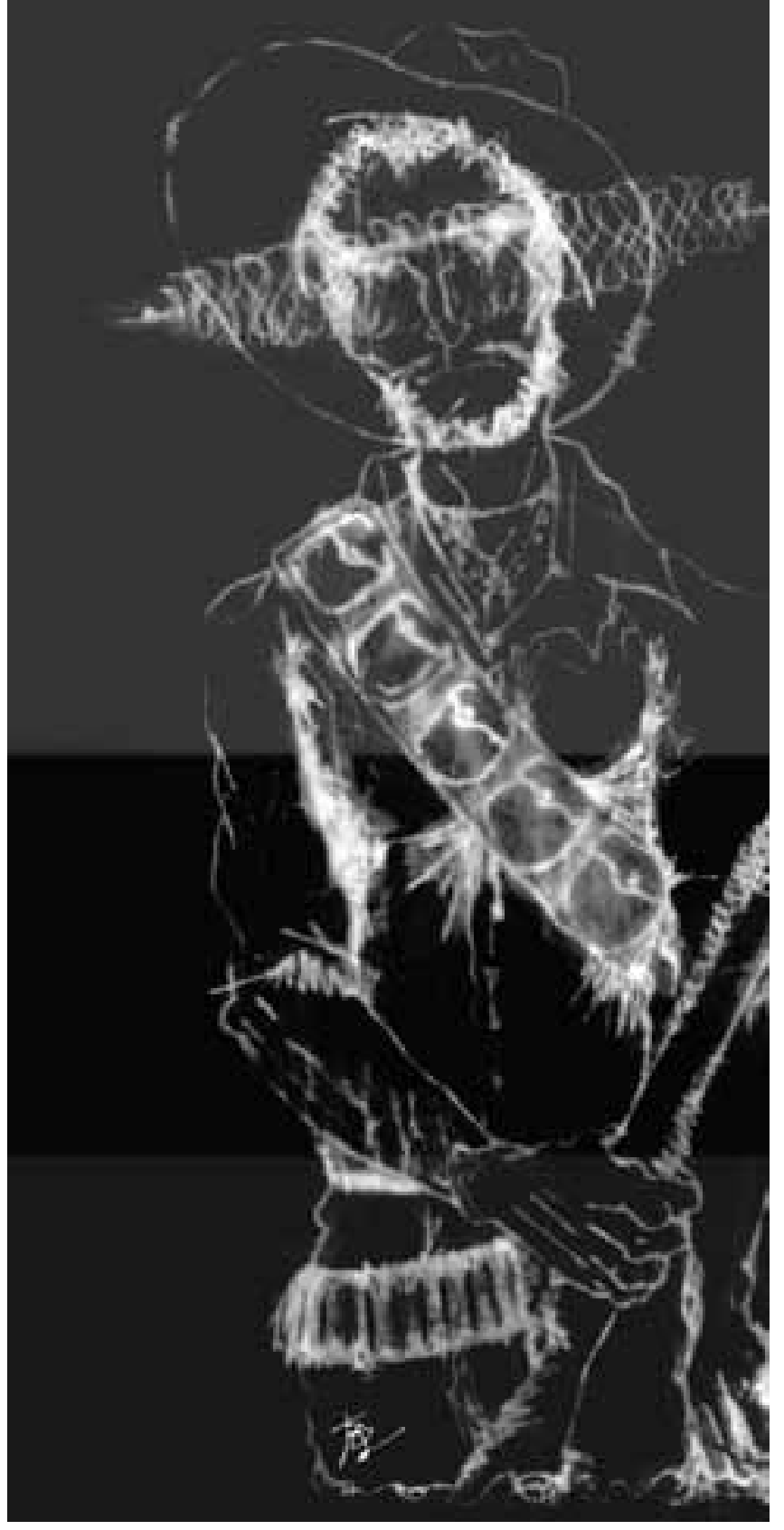

Pero ese legado no fue útil sólo durante la independencia. De acuerdo con König (1988: 189 ss.), el proceso de modernización emprendido a partir aproximadamente de 1840, y en adelante con los gobiernos reformistas liberales de mediados de siglo, recogieron algunas de esas banderas y las integraron a un proyecto nacional fundado en la promesa del progreso y del desarrollo económico y de la puesta a punto de la nación en relación con los países europeos. Y a esa promesa, tras el intento infructuoso de retornar a la unidad llamada la Gran Colombia, en 1863 se le dio el nombre de los Estados Unidos de Colombia para pasar con la Constitución de 1886 a ser nombrada la República de Colombia, nombre que ha mantenido desde entonces (Cock: 234-421). 
Pues bien, en la Nueva Granada la prensa desempeñó un papel significativo en tal dirección. Más que un órgano de información, la prensa fue durante el siglo XIX un medio de difusión de ideas y de debate político. Como afirma Carmen Elisa Acosta, siguiendo a José Antonio Amaya, los escritos publicados en el Papel Periódico de la Ciudad de Santa Fe de Bogotá "afianzaron el criollismo, y no sólo en la capital sino en otras ciudades y pueblos del virreinato" (2003: 53). En este sentido, cuando la Gran Colombia se disolvió la prensa se convirtió en un agente de promoción de ideas y de construcción de referentes para dar cuerpo a esa nación que habría de corresponder con el nuevo Estado: "la nueva sociedad propuso diversas funciones al naciente medio. Además de otorgarle el papel de portador de información lo hizo participar de manera activa en la construcción del discurso de y sobre la nacionalidad" (2003: $54)$.

Por otro lado, como subraya Anderson para el caso de Europa (1983: 63 ss.), la prensa no sólo informaba sobre lo que sucedía en la ciudad o el Estado donde era impresa. También lo hacía sobre otros lugares, aquellos que resultaban de algún interés por sus actividades comerciales. De esta manera, destaca este autor, la prensa instauraba la percepción de una simultaneidad fragmentada en distintos territorios. Y tales territorios correspondían a los espacios nacionales donde los habitantes locales se hacían conscientes de la existencia de otras naciones, de formas de alteridad, gracias a la circulación de información.

Pero la prensa no era el único medio a través del cual fluía información. Si los periódicos hablaban de la actualidad y del porvenir, otras producciones culturales lo hacían del pasado. O lo hacían sobre el presente organizando el pasado, buscando situar su tiempo en una tradición. Esa función la desempeñaban, por ejemplo, las artes, los museos y la literatura. Un caso particular en el que se aprecia esta función de la producción estética es la novela histórica ${ }^{16}$. Mezclando personajes y hechos históricos con personajes y hechos legendarios o totalmente inventados por los escritores, esas novelas contribuían a la construcción de un pasado nacional. De esta manera, la ficción devenía como instrumento ideológico útil a la edificación de representaciones de un pasado compartido.

Tal proceso no fue exclusivo de Europa. En América Latina y, en particular, en lo que hoy es Colombia, durante el siglo XIX la ficción literaria también desempeñó un papel decisivo en la configuración de una imagen del pasado y, más aún, de una imagen de lo que se quería ser en el presente y proyectar hacia el futuro. Recordemos que desde los tiempos coloniales lo que acontecía era el material de los escritores, tal como ocurría desde el célebre caso del Inca Garcilaso con sus Comentarios reales $(1609,1617)$. Por eso, como afirma Doris Sommer (1993), es plausible sostener que en América Latina la literatura, y en particular la novela, fue un medio privilegiado a través del cual se "fundaron las naciones” en tanto con la ficción se instituyeron 
algunas imágenes concebidas por las clases dirigentes de las nuevas naciones para generar sentimientos de unidad alrededor de valores nacionales. Sobre todo cuando la enseñanza se institucionalizó y la escuela se convirtió en escenario de formación de valores nacionales ${ }^{17}$.

Si por el momento sólo se ha hecho referencia a la prensa y al libro como precursores de los mass media y a la literatura como una máquina privilegiada para producir ficciones, hay que agregar que en casi todo el siglo XX y hasta hoy el cine - como también la televisión - ha copado parte del espacio que otrora ocuparan los periódicos y las novelas. Como afirma el crítico Omar Rincón, “en la historia de los medios de comunicación asistimos a la invención de una nación por la palabra, la voz y la imagen" (2003: 39). Con los medios que surgen y se desarrollan en el siglo XIX como fruto de los avances tecnológicos y del auge de la economía capitalista se da un salto enorme en la producción, difusión y consumo de información. A pesar de las desigualdades sociales y económicas, serán más las personas que accedan a los contenidos difundidos por medios masivos como la radio, el cine y la televisión. Esto es, de acuerdo con Martín-Barbero, que "fue en un discurso de masa donde lo nacional-popular se hizo reconocible para las mayorías” (1998: 223). Merece la pena resaltar, entonces, que como sucedía con la literatura, cuando en Colombia fue posible la realización de películas la ficción, ahora en su expresión cinematográfica, continuó desempeñando esa función.

\section{Cine e identidad}

Octavio Getino (1996: 137 ss.) cuenta que la irrupción del cine en América Latina ocurrió en 1896 en Brasil, fue casi inmediata a la primera exhibición comercial realizada por los Lumiére en Francia. Poco después, el proyector fue utilizado tanto en países de Sur y Centro América para popularizar su uso. Getino destaca que de un modo análogo a como había sucedido con los Cronistas de Indias, las primeras imágenes realizadas en el continente y sobre él fueron hechas por los técnicos y comerciantes europeos que habían traído el cinematógrafo. Pero pronto a esa producción se sumó la de realizadores locales, dando lugar así a dos tipos de productos. Según Getino, ya en los primeros años del siglo XX se harían los primeros productos cinematográficos de ficción "y con ellos el interés de consumidores y productores de reconstruir en imágenes los hechos históricos más relevantes de cada país o los acontecimientos de mayor impacto en la cotidianidad de cada pueblo" (1996: 139).

Por su parte, refiriéndose a América Latina Martín-Barbero afirma que el "cine en algunos países y la radio en casi todos proporcionaron a las gentes de las diferentes regiones y provincias una primera vivencia cotidiana de la Nación” (1998: 223). Por lo que respecta al cine, para restringirnos a los países de habla castellana se sabe que en México y Argentina la cinematografía cumplió un papel importante en la construcción y el afianzamiento del sentimiento de identificación con lo nacional en las primeras décadas del siglo $\mathrm{XX}^{18}$. Hay en esto, como lo resalta Martín-Barbero citando a Monsiváis, un poder particular asociado a la imagen: la posibilidad para los habitantes de un territorio de verse en unos signos icónicos e identificarse con ellos. Dice Martín-Barbero: 
Más allá de lo reaccionario de los contenidos y de los esquematismos de forma, el cine va a conectar con el hambre de las masas por hacerse visibles socialmente. Y se va a inscribir en ese movimiento poniendo imagen y voz a la "identidad nacional”. Pues al cine la gente va a verse, en una secuencia de imágenes que más que argumentos les entrega gestos, rostros, modos de hablar y caminar, paisajes, colores. Y al permitir al pueblo verse, lo nacionaliza. No le otorga nacionalidad, pero sí los modos de resentirla (1998: 223).

De la cita bien vale la pena resaltar la última frase: las imágenes que entrega el cine otorgan modos de sentir lo nacional, esto es, lo que se asocia — ya sea de manera consciente o no- con lo característico y propio de una nación. De hecho, el cómo nos ven es históricamente la primera situación puesta entre interrogantes con la llegada del cinematógrafo a Colombia en 1897. Recordemos, como lo describen, entre otros, Martínez Pardo (1978) y Zuluaga (2007), que las primeras "vistas" del territorio colombiano fueron hechas por extranjeros itinerantes que explotaban comercialmente artefactos recientemente inventados como el proyectoscopio y el cinematógrafo. Zuluaga, por ejemplo, reproduce una nota de prensa de 1899 en la cual un cronista caleño del diario El Ferrocarril manifiesta su descontento por algunas imágenes cinematográficas de su ciudad:

\footnotetext{
Nos permitirá el empresario unas observaciones (...) que suprima las vistas de calles y edificios de Cali; pues parece que no han sido tomadas con bastante arte: la del puente, por ejemplo, ¿por qué no se tomó de manera que se vieran las hermosas ceibas?, y la de San Francisco, de manera que se vieran su frontis ó su interior (reproducción fotográfica de un fragmento de prensa, en Zuluaga, 2007: 19).
}

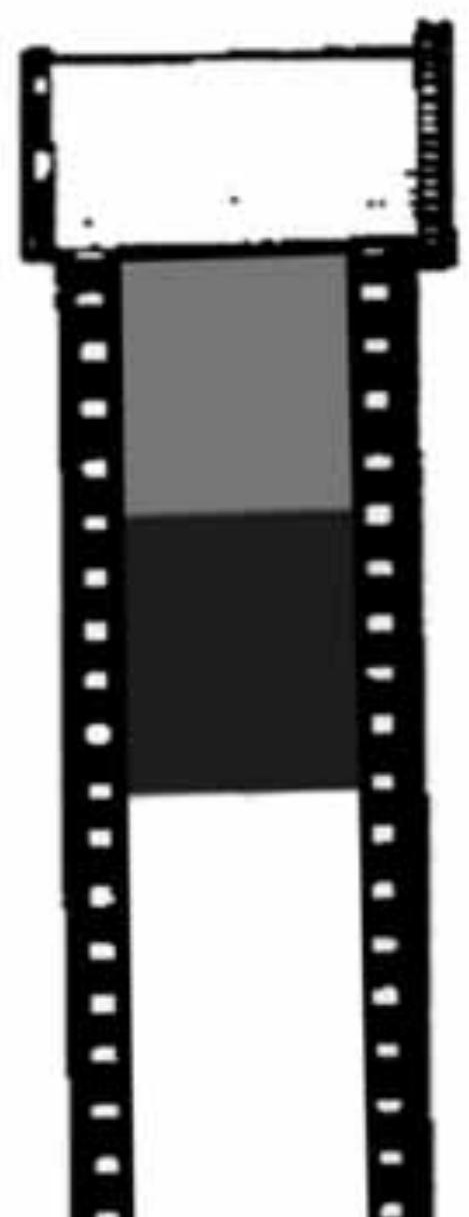

Con razón, Zuluaga comenta sobre esta nota que "(s)altan a la vista las ideas preconcebidas de lo que se debe o no mostrar, de cómo nos queremos ver” (2007: 18). La lectura contemporánea de aquellos productos nos permite, además, observar que en el periodo del cine silente la ficción y el documental sirvieron al propósito de proyectar una imagen deseada del país. O, más exactamente, la imagen del país y del estamento social, económico y político al cual pertenecían aquellos que tenían los recursos y el poder suficientes para realizar o encargar la realización de películas.

De acuerdo con Martínez Pardo, en 1915 los italianos Di Domenico anunciaban para el alquiler las películas Procesión del Corpus en Bogotá, en 1915, Procesión Cívica del 18 de julio de 1915, Una notabilidad rural (Cómica), La hija del Tequendama (Cuatro actos-drama). Si bien no se puede ignorar que a los empresarios los movía el interés de derivar ganancias de las películas, por lo que respecta a algunos de estos títulos se pueden intuir algunos hechos que, a juicio de los productores y realizadores, resultaban del interés para los espectadores de su tiempo y que actuaban como un reflejo de lo característico del país. En efecto, Martínez Pardo cita una nota de prensa de 1916 en la que se destaca cómo los productos cinematográficos eran promocionados como medios para conocer a Colombia: 
En el Diario de Panamá encontramos el siguiente aviso que reproducimos para que se vea la propaganda que le hacen a Colombia los fabricantes de películas nacionales: Quiere usted conocer a Bogotá, la capital de Colombia y darse una idea de las costumbres que allí imperan? Pues vayan esta noche a 'El Dorado' y verá (Sic) con todos sus pelos y señales la procesión del Corpus, tal como se acostumbra todavía en España (Martínez Pardo, 1978: 42).

De estos ejemplos se advierte, por lo menos, la presencia de la religiosidad como constante temática y del género del relato de viajes como estrategia discursiva y retórica para acercarse a lo desconocido y exótico ${ }^{19}$. De otro lado, la investigadora Juana Suárez (2009) destaca el interés propagandístico de las actualidades o actualités realizadas bajo encargo por otros pioneros del cine en Colombia: los Acevedo. De esta faceta del trabajo de los Acevedo cabe destacar la imagen positivista, del ingreso del país a la modernidad, proyectada en cumplimiento del encargo que les hizo el presidente Enrique Olaya Herrera. Aquí vemos como en el primer tercio del siglo XX el cine servía a la construcción de una imagen del país. Según Suárez,

Los noticieros de los Acevedo, particularmente aquellos producidos durante el periodo presidencial de Enrique Olaya Herrera (1930-1934), dan cuenta de la estrecha relación entre cine y tecnología y la tendencia en esos tiempos de acomodar la labor fílmica al proselitismo político. Al igual que en otros países latinoamericanos, el cine servía como un terreno para representar, documentar y proyectar la transición de lo rural a lo urbano (Suárez, 2009: 32).

En ese periodo el cine de ficción también aportó a la configuración de imágenes de la nación. Así lo testifican películas —o lo que queda de ellas - como El drama del 15 de octubre (1915), María (1922), Aura o las violetas (1924), Bajo el cielo antioqueño (1926), Alma provinciana (1926) o Garras de oro (1926). Como lo había hecho la literatura en el siglo XIX, en el XX la nueva factoría de ficciones y entretenimiento emergía para ganarse un lugar en el mercado de las representaciones. La afirmación de lo propio y, por extensión, la demarcación de lo extraño o lo que se deseaba superar en un país ansioso de modernidad también venían a determinar parte del contenido de la nueva práctica artística.

Para hacer referencia sólo a algunas de estas películas, cabe recordar que tanto María como Aura o las violetas surgen de la transposición al cine de sendas novelas. Para la época María de Jorge Isaacs ya era una obra canonizada en las literaturas colombiana e hispanoamericana. En ella se recogían valores oficializados. La investigadora Ana María López (2000), haciendo uso del concepto acuñado por Doris Sommer, también destaca el recurso de los primeros realizadores en Colombia de llevar al cine una obra de ficción fundacional de la idea de nación. En una entrevista recogida por Martínez Pardo, Pedro Moreno Garzón, director junto a Vicente Di Domenico de Aura o las violetas, contó que "se me encomendó que buscara un tema colombiano para filmarlo. Después de pensar en varias, escogí la popular novela de Vargas Vila 'Aura o las violetas'” (Martínez Pardo, 1978: 47. Las cursivas son mías). 
Bajo el cielo antioqueño, por otra parte, alberga la imagen positivista, arraigada en valores como la iniciativa comercial, el trabajo y el progreso, de los cuales se enorgullece la dirigencia económica y política de Medellín y toda una tradición que ésta ha fomentado. Definida por Paranaguá (2003: 64) como un retrato colectivo, esta película fue diseñada, pagada y actuada por un hombre de negocios y los de su círculo $^{20}$. Y Garras de oro, la película que aún hoy es una fuente de enigmas, con una explícita postura ideológica y política plantea cuestiones problemáticas en torno de las relaciones con una alteridad ya no inscrita en el marco de las diferencias raciales o de clase, sino en el de las relaciones internacionales, entre Estados.

Interesa destacar en este punto que a comienzos del siglo XX el cine de ficción constituyó una fuente de imágenes de lo que se consideraba propio o impropio de diversas clases o sectores sociales del país. La presencia en los contenidos cinematográficos de ciertos elementos materiales, espacios, personajes, situaciones, conflictos y relaciones, entre otros factores, dan cuenta de cómo los productores y autores de las películas se veían a sí mismos y cómo veían a los otros, cómo querían ser vistos y reconocidos. De María, por ejemplo, Martínez Pardo comenta que el "grupo de actores estuvo constituido por la 'alta sociedad' del Valle" (1978: 46). De ahí que el historiador sostenga que "aquellos melodramas y tragedias expresaban los valores, normas sociales y representaciones de la realidad que se daba nuestra burguesía y se transmitían a través de las instituciones” (1978: 60). Es decir, estas películas permiten mostrar cómo, desde los inicios de nuestra cinematografía, el cine ha sido un proveedor de las imágenes que han contribuido a conformar las representaciones de nosotros mismos y de los otros.

Como afirma Juana Suárez, el rechazo generalizado que en su momento se produjo contra El drama del 15 de octubre, por recrear la muerte del General Rafael Uribe Uribe incluyendo en el reparto del filme a los asesinos, deja ver el "hecho de que la recepción del cine colombiano por el público nacional empezó apegada a la concepción de este arte como un elemento de propaganda y difusión de una imagen positiva del país" (2009: 30). Por su parte, Chaparro Valderrama también ha llamado la atención sobre esta circunstancia. Este crítico apunta que "El drama del 15 de octubre, realizada en Bogotá por la empresa Di Doménico Hermanos, cifró el carácter vergonzante de una comunidad a la que no es difícil considerar como una de las más cinematográficas del mundo por la obsesión con su imagen, más todavía cuando enseña el caos que nos agobia” $(2006: 36)^{21}$. 
El cómo nos mostramos, cómo somos vistos y cómo vemos a otros en el cine son cuestiones que siguen manteniendo vigencia, aunque hoy se abordan en un orden diferente. En un orden cultural, económico y político condicionado por la globalización, las migraciones y los diluvios de información, la cuestión de las identidades nacionales no se piensa sólo dentro de las fronteras de un territorio. De hecho, en el orden actual la noción de fronteras se ha hecho (más) problemática y los grandes relatos, si creemos en el metarrelato de Lyotard, han cedido parte del poder que alguna vez se les asignara y han dado lugar a la diversidad de relatos. Pero aún así, y como una reacción a ese cambio, relatos que buscan proteger formaciones identitarias como los discursos nacionalistas se han manifestado con vigor. De ahí que guarden vigencia algunas preguntas sobre la relación entre el cine actual y los discursos identitarios y nacionalistas: cuáles discursos refuerza o cuestiona el cine. En este marco de ideas, qué dicen, qué muestran, qué no muestran y hacia dónde se orientan las películas que recientemente se han producido o coproducido en el país.

\section{Observaciones finales}

Por lo visto, no sólo la prensa o las producciones culturales - como la historia - que se supone están sometidas a un régimen creativo respetuoso de los acontecimientos, sino también la ficción contribuye a alimentar la idea de una supuesta unidad nacional - o a criticarla, con lo cual ya le reconoce cierta existencia. Lo que no deja de ser irónico es que si una comunidad sirve de asiento a una identidad, que si una nación es una comunidad imaginada y que si las tradiciones son inventadas, todas estas invenciones pueden encontrar uno de sus mayores soportes en la ficción artística.

Aquí merece la pena recordar un aspecto conflictivo de la relación entre los medios y las producciones discursivas que, como el cine, contribuyen a la construcción de identidades colectivas. La nación, como quedó dicho, no es una realidad fáctica, objetivable. El cine, ya sea de ficción o de no ficción, no reproduce la realidad. Como relato, como producción discursiva, al igual que los medios el cine construye versiones de lo real, proporciona representaciones que inciden en el modo de ver y entender el acontecer histórico. En este sentido, el cine y los medios en general tampoco reproducen la identidad nacional o colectiva. "La nación no puede ser pensada como un objeto o un discurso constituido del cual puedan dar cuenta los medios desde su particular lenguaje" (Arias, 2008: 216). El cine de ficción, entonces, con sus recursos y desde su ámbito puede contribuir a la construcción de las imágenes con las cuales se conforma una idea de nación. Como dice Juan Carlos Arias, la "nación mediática no debe comprenderse como un artefacto ficcional que dé cuenta de una supuesta 'nación real'. Si podemos hablar de nación es en la medida en que ésta sólo adquiere existencia en esa ficción, en ese artefacto mediático aunque no se reduzca a la construcción de los medios" $(2008: 216)^{22}$. 
Aunque pueda parecer superfluo recordarlo, es necesario precisar que el cine no es el único medio que a comienzos del siglo XX proporcionó y que en la actualidad proporciona imágenes que ayudan — ya sea porque se acepten o se rechacen - a la configuración de unos referentes identitarios. Como se deduce a propósito de lo dicho sobre la prensa y la literatura, ese poder lo ha compartido el cine con otros medios y con diversidad de productos y de prácticas culturales. Es evidente que con el tiempo ha habido cambios sociales y culturales significativos, y que la situación actual del cine no es igual a la de la primera mitad del siglo XX. Sin embargo, el hecho es que desde que existe, y a pesar del surgimiento de medios como la televisión y de recursos como la Internet, el cine sigue siendo una fuente de imágenes que hablan de nosotros y de los otros, de cómo nos miran, cómo miramos, cómo nos mostramos y cómo nos sentimos mirados.

Pensar la relación que se establece actualmente entre la representación de la identidad y los discursos del cine también es importante por otros motivos. Por una parte, por lo que obedece a la pregunta sobre las subjetividades sociales que construyen esos discursos, sobre cuáles son las lógicas que pueden regir su quehacer y, más aún, sobre cuáles son los discursos de mayor circulación y sobre qué incluyen y excluyen sus tramas. Y, por otra parte, por lo que respecta al punto inicial de esta exposición: si la identidad no es una esencia, sino un constructo discursivo e histórico, los contenidos de los discursos con los cuales se asocian los distintos miembros de una comunidad y las posiciones que éstos ocupan en las tramas incidirán en la construcción de los discursos identitarios. ¿Qué afirma y qué niega hoy una película acerca de un país? ¿Con qué identifica su gente y de qué la diferencia? ¿Hay coincidencias o distancias con los discursos nacionalistas enarbolados desde instancias públicas y privadas? Martín-Barbero sintetiza así esta doble cuestión:

\footnotetext{
El nuevo imaginario relaciona identidad mucho menos con mismidades y esencias y mucho más con narraciones, con relatos. Para lo cual la polisemia en castellano del verbo contar es largamente significativa. Contar es tanto narrar historias como ser tenidos en cuenta por los otros. Lo que significa que para ser reconocidos necesitamos contar nuestro relato, pues no existe identidad sin narración ya que ésta no es sólo expresiva sino constitutiva de lo que somos (2001: 23).
}

En este orden de ideas, hay que recordar que los referentes identitarios que ofrece el cine se producen enmarcados en las lógicas características de este tipo de producto cultural. Esto es, dentro de los parámetros que rigen al cine como industria y, en los casos más felices, como arte. La cuestión tiene que ver, desde luego, con la inserción del cine dentro de un discurso que, contra lo que sugiere Lyotard, se planta como un relato extendido a los más diversos ámbitos: el del rédito económico. Si bien no siempre es así, en este marco lo más frecuente es la recuperación de la inversión de los productores y, en una economía global, el predominio de la concepción de las películas como productos exportables, susceptibles de llegar a diversidad de públicos ${ }^{23}$, y como coproducciones de inversores de distintos países cuyos orígenes a veces se reflejan en los contenidos de los filmes. En la práctica, esto se puede traducir en las películas en la selección de actores de acuerdo con los países coproductores y en la hegemonía de esquemas narrativos y de agendas temáticas. Sin embargo, esta cuestión también tiene que ver con factores como, por ejemplo, la relativa autonomía con la cual los responsables de los proyectos acometen su ejecución, con las apuestas de los guionistas, directores y actores con determinado tipo de cine y con las decisiones de los organismos públicos y privados que contribuyen a la financiación de los proyectos cinematográficos. 


\section{Bibliografía}

Acosta, Carmen Elisa (2003). "La palabra en la construcción de la nacionalidad". VVAA (2003). Medios y nación. Historia de los medios de comunicación en Colombia. Bogotá:VII Cátedra anual de historia Ernesto Restrepo- Ministerio de Cultura, pp. 50-59.

Acosta, Luisa Fernanda (2008). "Investigación sobre cine en Colombia. De aficionados a cibernautas". Cuadernos de cine colombiano $N^{\circ} 13$, Bogotá: Cinemateca Distrital, pp. 22-37.

Adorno, Theodor (1959). “QQué significa elaborar el pasado?”. Crítica de la cultura y sociedad II. Madrid: Akal, 2009, pp. 489-503.

Aínsa, Fernando (1986). Identidad cultural de Iberoamérica en su narrativa. Madrid: Gredos.

Anderson, Benedict (1983). Comunidades imaginadas. México: FCE: 1993.Arciniegas Germán (1945). América, tierra firme y otros ensayos. Caracas: Biblioteca Ayacucho, 1990.

Arias, Juan Carlos (2008). "El discurso nacionalista en los medios audiovisuales, periodísticos y publicitarios (2005-2006)”. Signo y pensamiento. Bogotá: Vol. 27, N 53, pp. 213-219, jul-dic.

Arruda A., Alba Martha de (coords.) (2007). Espacios imaginarios y representaciones sociales. Barcelona: Anthropos.

Bauman, Zygmunt (1999). En busca de la política. Buenos Aires: FCE, 2001. (2001a). La sociedad individualizada. Madrid: Cátedra. (2001b). Comunidad: en busca de seguridad en un mundo hostil.

Madrid: Siglo XXI, 2003.

Cock Hincapié, Olga (1998). Historia del nombre de Colombia. Bogotá: Instituto Caro y Cuervo.

García Canclini, Néstor (1995). Consumidores y ciudadanos. Conflictos multiculturales de la globalización. México: Grijalbo.

Getino, Octavio (1996). La tercera mirada. Panorama del audiovisual latinoamericano. Buenos Aires: Paidós.

Guerrero A., Lozada M. (2007). “América latina: invasión, invención y creación”. Arruda A., Alba Martha de (coords.) (2007). Espacios imaginarios y representaciones sociales. Barcelona: Anthropos: 25-46.

Habermas, Jurgen (1961). Historia y crítica de la opinión pública. Barcelona: Gustavo Gili, 1994.

Hall Stuart (1996). "Quién necesita identidad”. Hall Stuart, Du Gay Paul (comps.) (1996). Cuestiones de identidad cultural. Buenos Aires: Amorrortu, 2003: 13-39.

Hobsbawm, Eric \& Ranger, Terence (eds.) (1983). The invention of tradition. Inglaterra: Cambridge University Press.

König, Hans-Joachim (1988). En el camino hacia la nación. Bogotá: Banco de la República, 1994.

Leftwich, Adrian (1984). ¿Qué es la política? La actividad y su estudio. México: FCE, 1996.

Martín Barbero, Jesús (1998). De los medios a las mediaciones. Bogotá: CAB. 
Martín Barbero, Jesús (2001). “Colombia: ausencia de relato y desubicaciones de lo nacional”, pp. 17-29. Martín Barbero, Jesús (comp.) (2001). Imaginarios de nación. Pensar en medio de la tormenta. Bogotá: Mincultura, pp. 17-29.

Martínez Pardo, Hernando (1978). Historia del cine colombiano. Bogotá: editorial América Latina.

Nancy, Jean Luc (1986). La comunidad desobrada. Madrid: Arena libros, 2001.

Paranaguá, Antonio (2003). Tradición y modernidad en el cine de América Latina. Madrid: FCE.

Pineda Botero, Álvaro (1997). "Yngermina. La historia en la primera novela colombiana”. Kohut Karl, Köning

Hans-Joachim (eds.) (1997). La invención del pasado. La novela histórica en el marco de la posmodernidad. Frankfurt am Main: Vervuert; Madrid: Iberoamericana: 143-166.

Ricoeur, Paul (1983). Tiempo y narración I. Configuración del tiempo en el relato histórico. Madrid: Ediciones Cristiandad, 1987.

Ricoeur, Paul (1990). Sí mismo como otro. Madrid: Siglo XXI, 1996.

(1999). Historia y narratividad. Barcelona: Paidós.Ricoeur Paul (2000). "La memoria ejercida: uso y abuso”. La memoria, la historia, el olvido. Buenos Aires: FCE, pp. 81-123.

Rincón, Omar (2003). "Introducción”. VVAA (2003). Medios y nación. Historia de los medios de comunicación en Colombia. Bogotá: VII Cátedra anual de historia Ernesto Restrepo- Ministerio de Cultura, pp. 38-47.

Sennett, Richard (1978). El declive del hombre público. Buenos Aires: Península.

Sommer, Doris (1993). Ficciones fundacionales. Las novelas nacionales de América Latina. Bogotá: FCE, 2004.

Suárez, Juana (2009). Cinembargo Colombia. Ensayos críticos sobre cine y cultura. Santiago de Cali: Universidad del Valle.

VVAA (2003). Medios y nación. Historia de los medios de comunicación en Colombia. Bogotá: VII Cátedra anual de historia Ernesto Restrepo- Ministerio de Cultura.

White, Hayden (1973). Metahistoria: la imaginación histórica en el siglo XIX. México: FCE, 1992. (2003). El texto histórico como artefacto literario. Barcelona: Paidós.

Zuluaga, Pedro Adrián (2007). ¡Accion! Cine en Colombia. Bogotá: Museo Nacional de Colombia.

\section{Recursos electrónicos}

Chaparro Valderrama Hugo (2006). "Cine colombiano 1915-1933: La historia, el melodrama y su histeria”. Revista de Estudios Sociales, $\mathrm{N}^{\circ} 25$, diciembre, pp. 33-37. http://res.uniandes.edu.co/pdf/descargar.php?f=./data / Revista_No_25/06_Dossier4.pdf.Consulta marzo de 2010 


\section{Notas}

1 La investigación fue realizada entre septiembre de 2009 y junio de 2010 en la Escuela de Comunicación Social de la Universidad del Valle y está adscrita al Grupo de investigación en sonido, imagen y escritura audiovisual Caligari.

2 Ricoeur concibe la construcción de la identidad como una operación narrativa y, al referirse a la identidad individual, muestra que el sentido de una vida se da como una historia de vida. La trama del relato se presenta, entonces, como una síntesis de lo vivido, de la diversidad de hechos y situaciones protagonizadas por o relacionadas con un individuo. Tal diversidad adquiere un sentido en el orden que le impone una trama, en este caso la trama de un relato biográfico o autobiográfico. Es significativo que la necesidad y la probabilidad que une los acontecimientos de la trama son dos exigencias del propio relato: al relatar, lo vivido se mira retrospectivamente; lo que en la experiencia era un futuro incierto, cuando lo narramos, por la perspectiva que nos da el tiempo, lo comprendemos como una consecuencia lógica de los acontecimientos precedentes (1990: 141). Dirá Ricoeur: "la síntesis concordante-discordante hace que la contingencia del acontecimiento contribuya a la necesidad en cierto sentido retroactiva de la historia de una vida, con la que se iguala la identidad del personaje. Sí, el azar se cambia en destino” (1990: 147). En el caso de las identidades colectivas, de acuerdo con Ricoeur, se da un proceso análogo: las tramas que se configuran con unos $\mathrm{u}$ otros acontecimientos vividos o atribuidos a una comunidad arrojarán un sentido sobre la vida de esa comunidad. Los relatos producirán, entonces, los sentidos con los cuales quienes construyen las tramas imaginan el sentido de la vida comunitaria: "la identidad narrativa, sea de una persona, sea de una comunidad, sería el lugar buscado de este quiasmo entre historia y ficción. (...) La comprensión de sí es una interpretación; la interpretación de sí, a su vez, encuentra en la narración, entre otros signos y símbolos, una mediación privilegiada" (1990: 107, nota al pie).

3 A los elementos en los cuales se construye una pretendida unidad identitaria - el tiempo, la alteridad y, en el caso de los grupos, la violencia fundacional — Paul Ricoeur los llama "causas de la fragilidad de la identidad". Sobre la alteridad escribe: "Segunda causa de fragilidad: la confrontación con el otro, sentida como una amenaza. Es un hecho que el otro, por ser otro, viene a percibirse como un peligro para la propia identidad, la del nosotros como la del yo" (2000: 111).

${ }^{4} \mathrm{Al}$ respecto Ricoeur sostiene: "Hay que citar como primera causa de la fragilidad de la identidad su difícil relación con el tiempo; dificultad primera que justifica precisamente el recurso a la memoria, en cuanto componente temporal de la identidad, en unión con la evaluación del presente y la proyección del futuro". Cabe precisar, además, que la memoria no se reduce a la historia. Ricoeur insiste en que su postura "es un alegato a favor de la memoria como matriz de la historia" (2000: $110,118)$.

${ }^{5}$ Sobre la creación poética del pasado en la historia remito a los planteamientos de Hayden White. En particular, a sus libros Metahistoria: la imaginación histórica en la Europa del siglo XIX (1973) y El texto histórico como artefacto literario (2003). Remito también

a los textos de Paul Ricoeur Tiempo y narración I (1983) e Historia y narratividad (1999).

${ }^{6}$ No sobra aclarar que esta distinción formal de la sociedad moderna en una realidad social como la de Colombia no se puede verificar plenamente.

${ }^{7}$ En un texto en el cual Theodor Adorno aborda la cuestión del nacionalismo en Alemania antes y después de la II Guerra Mundial señala la base psicológica de la idea de nación y su relación con la economía: "La idea de nación, en la que se plasmó la unidad económica de los intereses de los burgueses libres y autónomos frente a las barreras territoriales del feudalismo, se ha convertido en una barrera frente al potencial de la sociedad. Y el nacionalismo es actual porque sólo la idea tradicional y eminentemente psicológica de nación, que sigue siendo expresión de la comunidad de intereses en la economía internacional, tiene fuerza suficiente para poner a centenares de millones de personas al servicio de unos fines que ellas no pueden considerar directamente suyos" (1959: 498). 
${ }^{8}$ Martín-Barbero destaca acerca de este cambio histórico: “Los fueros y particularidades regionales, en que se expresan las diferencias culturales, se convierten en obstáculos a la unidad nacional que sustenta al poder estatal" (1998: 116).

9 Bauman señala sobre este proceso de transformación: "En algún momento, sin embargo, las creencias populares se convirtieron en supersticiones, los hábitos populares se transformaron en signos de oscurantismo y vulgaridad, y los estilos de vida populares devinieron en falta de cultura. Este momento está bien definido dentro del continuum histórico. (...) podemos situar ese momento como el del principio de la construcción de la nación moderna y el nacimiento del poder moderno" (1999: 112-113).

${ }^{10}$ Según Hobsbawm “«Invented tradition» is taken to mean a set of practices, normally governed by overtly or tacitly accepted rules and of a ritual or simbolic nature, which seek to inculcate certain values and norms of behaviour by repetition, which automatically implies continuity with the past. In fact, where is posible, they normally attempt to establish continuity with a suitable historic past" (1983: 1).

11 Considerar la dimensión política de la nación y, en consecuencia, de los agentes que intervienen en su construcción implica adoptar una concepción de la política que, sin excluirla, trasciende la adscripción de su práctica a la disputa por el gobierno del Estado y de sus instituciones. En este sentido, aquí se adopta la caracterización de Adrian Leftwich de la política como proceso: "En el corazón del argumento estará la afirmación de que la política está en el centro de toda actividad social colectiva, formal e informal, pública y privada, en todos los grupos humanos, instituciones y sociedades, no sólo en algunos de ellos (...) La política abarca todas las actividades de cooperación y conflicto dentro y entre las sociedades, por medio de las cuales la especie humana organiza el uso, la producción y la distribución de los recursos humanos, los naturales y otros (...) el término (recurso) también denota cosas que no son materiales y en las que no se piensa de inmediato como "recursos", tales como el tiempo, la educación, la posición, la influencia, la oportunidad y el conocimiento" (1984: 123, 127, 128).

12 Bauman, por su parte, observa que el nacionalismo es una respuesta a la disolución de un tipo de relación directa y a la necesidad de establecer unos vínculos en el nuevo orden que introduce la nación: "Por ser el único enclave de vida, con la solitaria muerte como única alternativa, la tribu podía arreglárselas sin ideología, adoctrinamiento o propaganda, cosas de las que la nación no puede prescindir. Aunque las tribus no necesitan del "tribalismo", la nación necesita del "nacionalismo", ese credo curioso — por no decir incongruente — que simultáneamente proclama que la esencia precede a la existencia y que la existencia precede a la esencia” (1999: 172).

${ }^{13}$ Recordemos que cuando en Historia y crítica de la opinión pública (1961) Habermas traza la génesis histórica del sentido moderno de lo público, advierte en el siglo XVIII europeo tanto la emergencia del concepto de opinión pública como de una de las condiciones materiales que lo hicieron posible: el surgimiento de la prensa. Si bien antes de ese momento en el ámbito urbano existían otros medios donde circulaba y se intercambiaba información, o más propiamente espacios como los salones y los cafés, aunque fueran más las personas analfabetas que aquellas capaces de leer Habermas subraya que la prensa masificó el acceso a la información de interés común, «público». La circulación masiva de información de actualidad — sobre todo comercial — era recibida por una incipiente sociedad civil que, tras la Revolución Francesa y la caída del ancien régime, se diferenciaba del Estado como la instancia inventada para administrar un orden en el recién creado estado-nación. 
14 Como sabemos, el arribo de los europeos a lo que hoy se llama el continente americano, y en particular a la hoy denominada Hispanoamérica, estuvo determinado por una fuerte imaginería. Colón y los primeros conquistadores concibieron su desembarco en la isla Guanahani como su ingreso al Paraíso. Otros, como Cortez, en sus cartas consignaron sus empresas como hazañas heroicas. Y los llamados Cronistas de Indias, como Bernal Díaz, dieron fe de lo que acontecía fundiendo en sus escritos fantasías caballerescas con la narración de los acontecimientos que presenciaban. A ese rasgo habría de sumarse la cuestión del mestizaje. O más exactamente, la cuestión del mestizo. Como afirma Germán Arciniegas, “(en) el siglo XVIII se funden los elementos que van a formar al hombre americano. El blanco, el negro y el cobrizo entran a vivir por primera vez debajo de una misma fronda” (1945: 330). En efecto, la peculiaridad del pasado histórico y cultural latinoamericano se ha descrito como el lugar de confluencia de indígenas, españoles y africanos. En Latinoamérica el mestizaje fue adoptado por discursos artísticos y oficialistas como la base de la identidad. En el siglo XX, el escritor mexicano José Vasconcelos llegó incluso a elevar esta condición a la categoría de programa, pues con cierto dejo nietszcheano postuló la existencia de una «raza cósmica» latinoamericana, cuya peculiaridad marcaría la diferencia entre los latinoamericanos y el resto del mundo. Así, la cuestión del mestizaje, como entre otros lo advierte Fernando Aínsa, en nuestro continente pasó de ser una noción aplicada a la confluencia de etnias para convertirla en una categoría cultural de carácter esencialista.

15 Según König: "los derechos del ciudadano debían erigirse como criterio principal de la afiliación a la nación que habría de plasmarse dentro de las fronteras de la patria, del país de nacimiento entendido como unidad. De este modo, el nuevo Estado no podía sólo delimitarse positivamente ante el antiguo poder colonial; también le era posible demostrar que la pertenencia étnica y regional no implicaba una desigualdad, sino que precisamente la igualdad política representaba el rasgo característico del nuevo Estado y transformaba a los miembros de dicho Estado en una nación” (1988: 512).

16 Surgida al calor del romanticismo, cuando Napoleón expandía su imperio por Europa, la novela histórica constituyó una forma de reacción contra un presente tumultuoso y una vuelta a la búsqueda de unos presuntos orígenes. Walter Scott, a quien se considera el fundador del género, en sus obras aderezadas con batallas y aventuras localizaba a sus héroes en pasados medievales o más próximos a su época para fijar en el tiempo el origen de los rasgos de los combativos británicos. En Ivanhoe (1819), por ejemplo, el héroe lucha para derrotar y expulsar al invasor extranjero. Caso similar sucede en Los novios (1826), de Manzoni, considerada la novela que consigue crear una relativa unidad lingüística en Italia.

17 Doris Sommer (1993: 20-46) llama novelas de fundación nacional a aquellas obras canónicas que, a través de instituciones como la escuela, en el siglo XIX comunicaron un sentido de aquello valorado como identitario en distintas naciones. Se trata de novelas que, en su momento, con temas como el matrimonio y la familia fundieron los proyectos privados con los públicos, sirvieron de referente para la unión de parejas cuyos miembros representaban territorios distintos y así contribuyeron a crear imágenes de cohesión y unidad nacional. El hecho no es extraño, pues quienes tenían las condiciones necesarias para escribir eran, en la mayoría de los casos, personajes vinculados a la dirigencia política o a la clase hegemónica. Según Sommer: "Las novelas románticas se desarrollan mano a mano con la historia patriótica de América Latina. Juntas despertaron un ferviente deseo de felicidad doméstica que se desbordó en sueños de prosperidad nacional materializados en proyectos de construcción de naciones que invistieron a las pasiones privadas con objetivos públicos" (1993: 23). Recuérdese, por ejemplo, el mentado debate entre la civilización y la barbarie impulsado desde Argentina hacia todo el continente por Facundo (1844) de Sarmiento. O el caso de Amalia (1849) de José Mármol. En Colombia las cosas no eran muy diferentes. Aquí también la ficción literaria sirvió como medio para configurar una imagen propia. Novelas históricas como Yngermina (1844), del militar y político Juan José Nieto, o el Último rey de los muiscas (1864), de Jesús Silvestre Roso habían cumplido esa función (Pineda Botero: 1997). Y más adelante y con mayor penetración María (1867), de Jorge Isaacs, considerada por Sommer la novela de fundación nacional de Colombia. 
${ }^{8}$ Escribe Antonio Paranaguá: “Quizás pueda verse en el cine un laboratorio para los nacionalismos y populismos contemporáneos. Así como la «revolución lexicográfica» precedió a los nacionalismos europeos, la revolución cinematográfica fue un laboratorio para las comunidades imaginadas por el populismo latinoamericano" (2003: 222-223).

19 Hugo Chaparro Valderrama, por ejemplo, habla de que en 1913 "los Di Domenico exhiben en Medellín lo que es ahora parte de su arqueología cinematográfica —El escudo de Antioquia; Retratos de los Próceres y del Presidente de la República; Hidroplanos” (2006: 34). Zuluaga, por su parte, cita títulos como Primer Congreso Mariano Nacional y de homenaje a la virgen de Chiquinquirá (hermanos Di Domeneco, 1919) y De Barranquilla a Santa Martha y De Barranquilla a Cartagena (Floro Manco, 1916). Por esto afirma que en aquel periodo "el cine iba de la postal turística a la piadosa y de la piadosa a la comercial” (2007: 33).

20 Dice Paranaguá: "La metamorfosis de la tradición rural en modernidad urbana encontraba por lo tanto en el cine un campo de representación ideal, acorde con el paradigma moderno que se intentaba emular. El largometraje argumental Bajo el cielo antioqueño es un retrato colectivo - casi un álbum de familia - de la buena sociedad de Medellín de los años veinte, en plena evolución de las mentalidades y las costumbres" (2003: 64).

${ }^{21}$ Incluso, de ese juego de mostrar y ocultar ante los otros, Chaparro Valderrama recuerda: "también se llegó a la conclusión de prohibir en el extranjero la película Como los muertos, realizada en 1925 por Pedro Moreno Garzón y Vicenzo di Doménico, ya que su protagonista "aparecía señalado con el terrible mal bíblico" (la lepra), opinando el respetable "que se debía cambiar la enfermedad de Don Manuel por cualquier otra menos lesiva para nuestros intereses económicos”, de lo contrario bajaría sensiblemente el precio del café en el mundo" (Chaparro Valderrama, 2006: 36. También Martínez Pardo, 1978: 50).

22 Siguiendo a Arnheim, Juan Carlos Arias agrega acerca de la construcción de las imágenes de nación en el cine: "El cine se muestra así como uno de los medios a través de los cuales una serie de flujos, referentes e imaginarios informes se configuran como nación en la formalización de la imagen. El cine da forma a la nación, no simplemente porque nos haga conscientes de lo que ya estaba allí, pero no había sido revelado, sino porque moldea un objeto particular que, por medio de estrategias retóricas y discursivas, se erige como independiente a la imagen que le dio forma" (2008: 218).

${ }^{23}$ A propósito del cine en un orden globalizado, Juana Suárez comenta lo que sucedió con el guión de un proyecto de Víctor Gaviria en un certamen internacional: "En la edición de «En construcción» de Festival de Cine de San Sebastián de 2003, una de las razones para la descalificación de Sumas y restas fue la queja de la audiencia sobre el carácter ininteligible del español usado en la película" (Suárez, 2009: 191, nota al pie 6). 